\title{
JOURNAL
}

of Health Inequalities

\section{The alcohol crisis in Polish public health}

\author{
Witold A. Zatoński \\ European Observatory of Health Inequalities, the President Stanisław Wojciechowski State University of Applied Sciences \\ in Kalisz, Poland \\ Health Promotion Foundation, Nadarzyn, Poland
}

The decrease in spirits' excise taxation in 2002 [1] and aggressive marketing and product innovation by the alcohol industry [2] have led to a prolonged "health recession" in Poland. Only now are we starting to understand the scale of the public health crisis this has precipitated. The development of the health situation in Poland since the Second World War has been characterised by rapid fluctuations in life expectancy [3]. The 1990s were a decade of health convergence with the West, as life expectancy increased by 4 years among Polish men and 3 years among Polish women. The decline in premature mortality in this period belonged to the quickest in Europe [4].

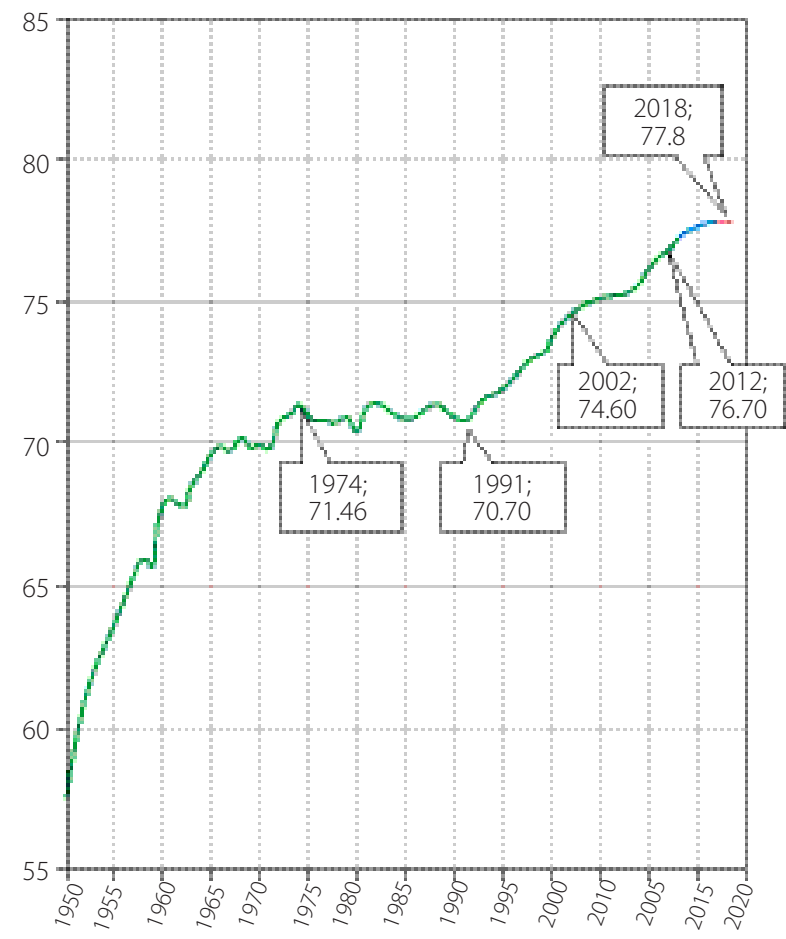

FIG. 1. Life expectancy, both sexes in Poland, 1950-2018
However, since 2003 Poland has experienced a return of increasing premature mortality among young and middle-aged adults. The main reason underpinning this trend is a sudden, dramatic rise in alcohol consumption [5] and the resulting increase in morbidity and mortality due to alcohol-related diseases and events $[3,4]$. Poland has seen a freezing of life expectancy not dissimilar to the trend recently observed in the United States [6]. In both cases the reason was unifactorial and was the biomedical consequence of a sudden increase in the use of psychoactive substances (alcohol in Poland, opiates in the USA).

In the years 1991-2002 life expectancy in Poland grew by around $7 \%$ among men and by $5 \%$ among women annually. In the years 2003-2007 life expectancy growth stalled at $0.1 \%$ annually. In the years 2008-2013 it picked up slightly to $0.6 \%$ in men and $0.3 \%$ in women annually. Finally, in the years 2013-2017 stagnation in life expectancy has been observed once again. In 2018, for the first time in the $21^{\text {st }}$ century, life expectancy in Poland has slightly decreased (Fig. 1).

In the last decade, apart from occasional research articles [3-5], there have not been any official publications or reports discussing the increase in alcohol consumption and its health effects in Poland. In a 2018 report by the Polish National Institute of Public Health - National Institute of Hygiene, the trends and structure of alcohol consumption in the last 15 years have not been highlighted [7]. Meanwhile, an OECD report, published in 2019, indicated that Poland is one of a handful of countries to have experienced an increase in alcohol consumption in the last decade [8]. The increase in the sale and consumption of alcohol in Poland in the years 2003-2018 from 6.5 to over 10 litres of pure spirit per year per capita has probably been the largest and fastest in the world [5, 8]. At the same time, the neighbouring Russia has seen a decline from 18 to 11 litres between 2007 and 2017 [8-10].

Most recently, in November 2019, the Polish daily Rzeczpospolita published data by the General Statistical Office (GUS) indicating very significant increases in 
alcohol production in Poland between January 2018 and September 2019, especially for vodka and beer [11]. In the case of vodka, the production has grown from 64,000 hectolitres to 87,500 hectolitres per month.

From the point of view of public health policy, the alcohol trends observed in Poland should be a cause for great concern. The most recent data for alcohol consumption, and especially the rapid increase in sale of small vodka bottles, suggests that we can expect an ongoing decline in health in Poland [3-5, 11]. However, the data on the sale and consumption of alcohol in Poland is far from complete.

A public health alarm needs to be sounded in Poland. Sound scientific investigation into the growing alcohol consumption and its health effects is sorely needed. The bleak, mass-scale, population-wide natural experiment occurring in Poland needs to be understood, described, and acted upon. Action is needed urgently and needs to be accompanied by the development of a comprehensive and well-funded national public health programme, with special attention to the health effects of alcohol consumption. The government needs to create a position of a Public Health Ombudsman who would take responsibility for coordinating action against what is fast becoming a national public health crisis.

\section{DISCLOSURE}

The author reports no conflict of interest.

\section{References}

1. Ordinance of the Minister of Finance of 01.08.2002, no. 1065. Available from: http://prawo.sejm.gov.pl/isap.nsf/DocDetails. xsp?id=WDU20021251065 (accessed: 18 June 2019).

2. Synergion. Where is the little vodka flowing? Report on the 'little vodka' market and the changes it causes in consumer behaviour. Available from: https://www.slideshare.net/synergion/synergion-raport-dokad-plynie-mala-wodka-2019 (accessed: 18 June 2019).

3. Zatoński WA. One hundred years of health in Poland. J Health Inequal 2019; 5 (1): 11-19.

4. Zatoński W, Sulkowska U, Zatoński M, et al. Alcohol taxation and premature mortality in Europe. Lancet 2015; 385 (9974): 1181.

5. Zatoński WA, Młoźniak I, Zatoński M, Gruszczyński Ł. Small bottles - huge problem? A new phase of Poland's ongoing alcohol epidemic. J Health Inequal 2019; 5 (1): 86-88.

6. Rehm J, Probst C. Decreases of life expectancy despite decreases in non-communicable disease mortality: the role of substance use and socioeconomic status. Eur Addict Res 2018; 24 (2): 53-59.

7. Wojtyniak B, Goryński P (eds.). Health status of Polish population and its determinants - in short. National Institute of Public Health - National Institute of Hygiene, Warsaw 2018. Available from: https://www.pzh.gov.pl/najnowszy-raport-nizp-pzh -sytuacja-zdrowotna-ludnosci-polski-i-jej-uwarunkowania/ (accessed: 14 November 2019).
8. OECD. Health at a glance 2019. OECD Indicators. OECD Publishing, Paris 2019.

9. Rehm J, Ferreira-Borges C. Risk factor policies, morbidity, and mortality in Russia. Lancet 2018; 392 (10153): 1094-1095.

10. GBD 2016 Russia Collaborators. The burden of disease in Russia from 1980 to 2016: a systematic analysis for the Global Burden of Disease Study 2016. Lancet 2018; 392 (10153): 11301146.

11. Ptak-Iglewska A. Pijemy coraz więcej alkoholi z wyższej półki [We are drinking more "top-shelf" alcohol brands]. Rzeczpospolita. Available from: https://www.rp.pl/Przemysl-spozywczy/311209885-Pijemy-coraz-wiecej-alkoholi-z-wyzszej-polki. html (accessed: 22 November 2019). 